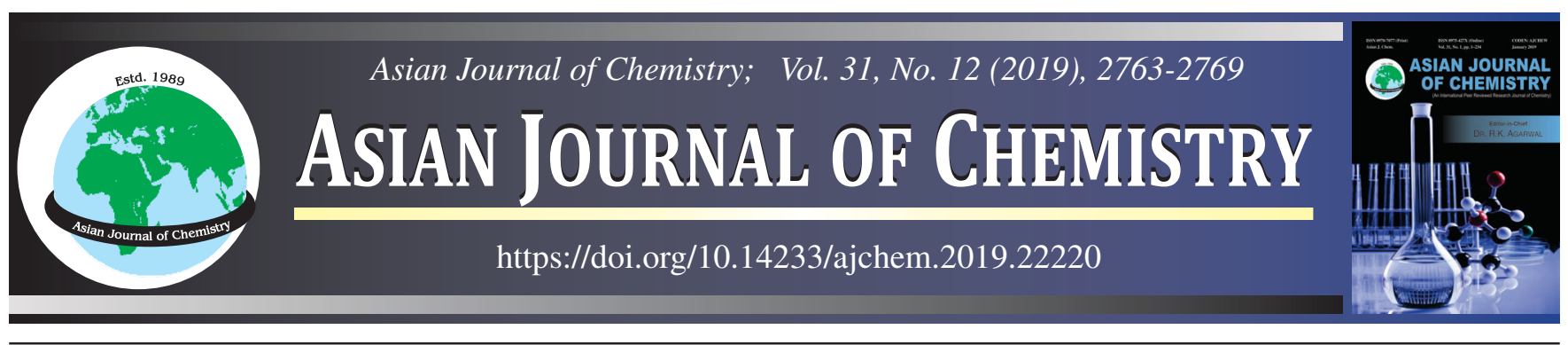

\title{
Identification and Characterization of Forced Degradation Products for Dofetilide using Rapid and Sensitive UPLC-MS/MS Method and HRMS Studies
}

M. Ajay Babu ${ }^{1,2, *}$, G.V. Krishna Mohan ${ }^{1}$, N. Naresh ${ }^{2}$, Ch. Krishnam Raju ${ }^{1,2}$ and Sharad D. Mankumare ${ }^{2}$

${ }^{1}$ Department of Chemistry, Koneru Lakshmaiah Education Foundation, Green Fields, Vaddeswaram-522502, India

${ }^{2}$ U.S.P. India Private Limited, IKP Knowledge Park, Hyderabad-500101, India

*Corresponding author: E-mail: ajaymakineni@yahoo.co.in

Received: 30 May 2019;

Accepted: 8 July 2019;

Published online: 16 November 2019;

AJC-19617

A simple, rapid and efficient method has been developed and validated using ultra UPLC combined with Q-ToF MS system for recognition
and characterization of forced degradation products obtained from dofetilide degradation studies. The dofetilide drug is an antiarrhythmic
and belongs to Class III and it was treated with various stress conditions like acidic, basic, oxidative, photolytic and thermal conditions as
per ICH guidelines. The main drug shows extensive degradation towards oxidative degradation conditions and single degradation product
was identified through chromatogram. The chromatographic separation among main and its impurities were attained through $2.1 \times 150$,
$1.8 \mu \mathrm{m}$ column from gradient elution using UPLC and its detection at wavelength $230 \mathrm{~nm}$. The validation was performed for the developed
method using various parameters like specificity, linearity and robustness studies. Waters Synapt G2 Q TOF system was used and performed
$\mathrm{MS}^{\mathrm{n}}$ studies to establish mass spectral fragmentation pathway for drug and its degradation products and determined accurate masses
study. The efficiency of this method was helpful to identify and characterize the drug and degradation products using LC/MS ${ }^{\mathrm{n}}$ techniques.

Keywords: Dofetilide, UPLC, Degradation products.

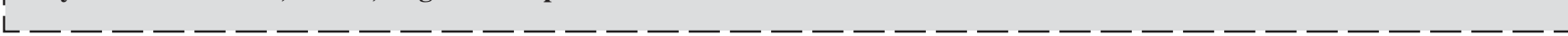

\section{INTRODUCTION}

Dofetilide (DFT) is a class III antiarrhythmic drug that acts as potassium channel blocker [1]. The chemical name of dofetilide is (N-[4-[2-[methyl[2-[4-(methylsulfonyl)amino]phenoxy]-ethyl]amino]ethyl]phenyl]methanesulfonamide). It is responsible for the maintenance of sinus rhythm in atrial fibrillation and atrial flutter. It was approved by USFDA in 1999 and it's dose recommended is $0.5 \mathrm{mg}$ per day twice [1,2]. Dofetilide is widely used for the treatment of patients with persistent atrial fibrillation. It has selective action against the potassium current and does not block the calcium channels in cardiac myocytes. It has no effect on cardiac output and index, stroke volume index and systemic vascular resistance [1-3].

Literature survey revealed the UV and HPTLC methods developed for analysis of dofetilide and its degradation products. Simultaneous determination of amlodipine and dofetilide in plasma using HPLC [2] and also the bioequivalence studies in volunteer under fasting and fed conditions for this drug is reported [3]. The in vitro evaluation study was done for formu- lation by using chronomodulated drug delivery [4]. The degradation studies using UV spectroscopy and HPLC are also reported [5]. In United States pharmacopeia edition USP41/NF36, the separation of dofetilide and impurity 1 in dofetilide monograph is mentioned, but no study about its degradation [6]. As per literature study, there is no systematic study and approach found for the method development, validation, degradation studies for dofetilide drug and its drug products by using UPLC.

The present study about method development and validation, identification of degradation products for dofetilide helps in further metabolic studies and determination of process related impurity during its bulk synthesis. The present research study focused in three phases viz. (a) Develop and validate a RPUPLC method for drug and its impurities. Picking out of degradation products formed within the course of application of assorted forced conditions on drug as per the ICH guidelines [7], (b) Degradation products were identified and characterized through $\mathrm{MS}^{\mathrm{n}}$ techniques, and (c) structures for identified degradation products were proposed and confirmed with the help of LC-MS/Q-TOF studies.

This is an open access journal, and articles are distributed under the terms of the Attribution 4.0 International (CC BY 4.0) License. This license lets others distribute, remix, tweak, and build upon your work, even commercially, as long as they credit the author for the original creation. You must give appropriate credit, provide a link to the license, and indicate if changes were made. 


\section{EXPERIMENTAL}

Samples of dofetilide and its impurity were acquired from USP India Pvt. Ltd., Hyderabad, India. The high quality grade solvents used such as acetonitrile, methanol and chemicals $v i z$. hydrogen peroxide, hydrochloric acid and sodium hydroxide were procured from Merck, Mumbai, India. The Milli-Q-Water water was acquired from Milli-Q-Water purification system (Millipore Corporation, USA).

Instrumentation: The Acquity UPLC system belongs to $\mathrm{H}$-Class consists of photodiode array (PDA) detector, Acquity UPLC HSS T3, $150 \mathrm{~mm} \times 2.1 \mathrm{~mm} ; 1.8 \mu \mathrm{m}$ particle size column from Waters Corporation are used for this research work related to chromatographic separation. The software named as Empower 3 was used for acquisition of data. The Sartorius balance was used for the weighing of chemicals and samples. For photolytic study, Atlas SUNTEST XLS+ (Atlas Material Testing, Illinois, USA) photo-stability chamber was used. For humidity stress study, Espec SH-642 Temperature and Humidity Bench top Chamber (Advanced Test Equipment Corporation, CA, USA) was used. For thermal stress study, hot air oven from Memmert Model 100-800 (Memmert GmbH + Co. KG, Schwabach, Germany) was used [6].

For LCMS/MS and MS ${ }^{\mathrm{n}}$ studies, Waters SYNAPT G2QTOF mass spectrometer coupled to an UPLC Acquity system belongs to $\mathrm{H}$-Class provided with a quaternary gradient pump was used. This study helps in identifying the degradation products formed during various degradation stress conditions and to know the molecular mass of degradation product. It helps in establishing the proposed chemical formula and structure. Mass accuracy study was performed to support the proposed chemical formula and structure for degradation product was accurate. The source for electrospray ionization (ESI) is positive ion mode. The parameters set for ESI source is as follows; capillary voltage: $3.25 \mathrm{kV}$, source temperature: $120^{\circ} \mathrm{C}$, desolvation temperature: $250{ }^{\circ} \mathrm{C}$, sampling cone: $40 \mathrm{~V}$, extract ion cone: $3.0 \mathrm{~V}$ and desolvation gas flow: $800 \mathrm{~L} \mathrm{~h}^{-1}$. The data acquired using Masslynx 4.1 software [8].

Chromatographic conditions: The chromatographic column used was Waters Acquity HSS T3 C18 $(150 \mathrm{~mm} \times 2.1 \mathrm{~mm})$ with $1.8 \mu \mathrm{m}$ particles. For mobile phase A, $0.1 \mathrm{mmol}$ ammonium acetate buffer ( $\mathrm{pH} 5$ ) was used and acetonitrile for mobile phase B. The $0.3 \mathrm{~mL} / \mathrm{min}^{-1}$ flow rate is maintained for mobile phase. The UPLC gradient program was set as time ( $\mathrm{min}) / \%$ Solution B: $0 / 25,2 / 25,8 / 60,12 / 60,12.5 / 25$ and $18 / 25$. The column temperature is maintained at $25^{\circ} \mathrm{C}$ and $230 \mathrm{~nm}$ wavelength is used for detection. About $2 \mu \mathrm{L}$ injection volume was used and the acetonitrile and water $(1: 9 \mathrm{v} / \mathrm{v})$ composition is used as diluent for this method. The concentration is $500 \mu \mathrm{g} \mathrm{mL}^{-1}$ for related substances (RS) and $100 \mu \mathrm{g} \mathrm{mL}^{-1}$ for assay.

Sample solution preparation for assay: About $10 \mathrm{mg}$ of dofetilide sample was weighed and transferred in a $100 \mathrm{~mL}$ volumetric flask and $70 \mathrm{~mL}$ of diluent is added to dissolve completely and made upto volume mark with diluent. The obtained concentration is $100 \mu \mathrm{g} \mathrm{mL}^{-1}$.

Preparation of organic impurities solution: About $10 \mathrm{mg}$ of dofetilide sample was weighed and transferred into $20 \mathrm{~mL}$ volumetric flask, $5 \mathrm{~mL}$ of diluent is added, dissolved it and made up to volume with diluent. The obtained concentration is $500 \mu \mathrm{g} \mathrm{mL}^{-1}$.
Preparation of impurity 1 standard solution: Impurity 1 stock solution at $100 \mu \mathrm{g} \mathrm{mL}^{-1}$ concentration was prepared in diluent.

Preparation of organic impurities standard solution: Stock solution of dofetilide and its impurity $1\left(100 \mu \mathrm{g} \mathrm{mL}^{-1}\right)$ was prepared by dissolving an appropriate amount in diluent. Working solution was prepared from above stock solution for organic impurities determination (1 dofetilide) in diluent. The chromatogram is shown in Fig. 1.
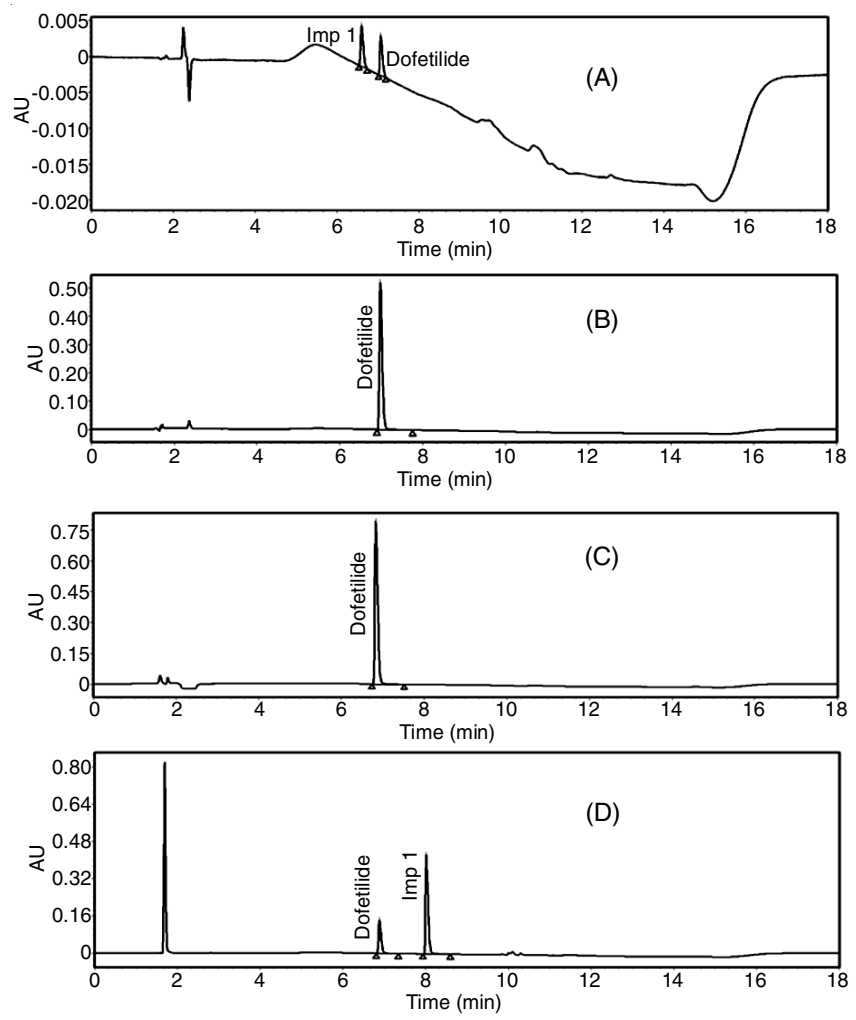

Fig. 1. Chromatograms of (A) organic impurities standard solution, (B) acid hydrolysis, (C) base hydrolysis, (D) peroxide degradation

Validation of analytical method: The UPLC method for the determination of dofetilide and its impurity 1 was validated according to ICH guidelines [9]. The parameters includes system suitability, linearity, accuracy, sensitivity, robustness and specificity were tested as a part of validation study.

System suitability: The solution containing mixture of dofetilide $\left(100 \mu \mathrm{g} \mathrm{mL}^{-1}\right)$ and its impurity $1\left(100 \mu \mathrm{g} \mathrm{mL}^{-1}\right)$ was injected in replicates to check the system suitability criteria. The criterion includes the following parameters like percentage $\mathrm{RSD}$, resolution, tailing factor and theoretical plates were checked and confirmed through this study. The criterion is as follows: resolution should be greater than 1.5, RSD value should not exceed $2.0 \%$, tailing factor is in between 0.7-1.3 and column efficiency is should be greater than 3000 in terms of theoretical plates.

Linearity and accuracy: The impurity concentrations at five different levels ranging from 0.0025 to $0.0075 \%$ with respect to analyte concentration were prepared from stock solutions as impurity linearity solutions. The test solutions were prepared at different levels of concentration from 50 to $150 \%$ containing 50, 75, 100, 125 and $150 \mu \mathrm{g} \mathrm{mL}^{-1}$ analyte concen- 
trations. The linearity curve was developed by plotting peak area responses against the concentrations $\left(\mu \mathrm{gLL}^{-1}\right)$.

For related substances method, accuracy was evaluated in triplicate at $0.005 \%$ to $1.0 \%$, of analyte concentration (500 $\left.\mu \mathrm{g} \mathrm{mL}^{-1}\right)$. The recovery for all impurities was calculated in percentage levels. For assay method, accuracy was evaluated in triplicate at three different 50 to $150 \mu \mathrm{g} \mathrm{mL}^{-1}$ concentration levels. Prepared three sample sets and injected in triplicate at each concentration.

Sensitivity: The sensitivity of this method was determined at a signal to noise $(\mathrm{S} / \mathrm{N})$ ratio of $3: 1$ and 10:1 for limit of detection (LOD) and limit of quantification (LOQ) for impurity 1. A series of diluted solutions are injected having known concentration of impurities for this study. Injected LOQ solutions containing impurity 1 for five times and determined the percentage RSD at LOQ level as a part of precision study [10].

Robustness: The robustness study was performed for the developed method was tested by changing the experimental conditions intentionally. The resolution (Rs) between dofetilide and impurity was evaluated as a part of system suitability. The actual mobile phase flow rate was $0.3 \mathrm{~mL} \mathrm{~min}^{-1}$ for this method. For identifying the flow rate effect on this method, slight modifications were done by changing \pm 0.02 flow units (i.e. 0.28 and $\left.0.32 \mathrm{~mL} \mathrm{~min}^{-1}\right)$. The column temperature effect was performed at 20 and $30^{\circ} \mathrm{C}$ instead of at $25^{\circ} \mathrm{C}$. The mobile phase composition was remained same constant in all of the above varied conditions.

Specificity: Stress studies were carried out for drug substance to identify the possible degradation products. This study helps to establish the degradation pathways and the inherent stability of the molecule. As per ICH guidelines [11], degradation studies were performed under various stressed conditions to make available of the specificity and stability indicating properties of method. The various degradation studies were conducted in various stress conditions as follows: acid $(0.1 \mathrm{M}$ $\mathrm{HCl}$ for $24 \mathrm{~h}$ at room temperature), base $(0.1 \mathrm{M} \mathrm{NaOH}$ for $24 \mathrm{~h}$ at room temperature), oxidation ( $6 \%$ peroxide for $3 \mathrm{~h}$ at room temperature), thermal (exposed at $105^{\circ} \mathrm{C}$ for $48 \mathrm{~h}$ ), humidity (exposed to $85^{\circ} \mathrm{C}$ and $85 \% \mathrm{RH}$ for 3 days) and photolytic stress (1.2 million lux hours followed by 200 watt-hours $/ \mathrm{m}^{2}$ ).

\section{RESULTS AND DISCUSSION}

The individual stock solutions of dofetilide and its impurity were injected and scanned from 200 to $400 \mathrm{~nm}$ wavelength range using photodiode array detector and identified the absorbance maxima of dofetilide and its impurity from individual spectrum. The absorbance maxima identified for dofetilide and its impurity is about $230 \mathrm{~nm}$. Hence, the wavelength at $230 \mathrm{~nm}$ was selected and further continued the research work for identification and determination of dofetilide and its impurities.
The PDA detector was used for LC method development and validation and LC-MS detector was used for the scanning of dofetilide and its impurities and identified the $\mathrm{m} / \mathrm{z}$ values for dofetilide and its impurity. The system suitability results from UPLC and $m / z$ values from mass spectrum are given in Table1. The concentration of $\mu \mathrm{g} \mathrm{mL}^{-1}$ of impurity is used for the spiking of $1000 \mu \mathrm{g} \mathrm{mL}^{-1} \mathrm{DFT}$ sample preparation. This spiked solution was used for the method development and separation by RP-UPLC using different buffers, columns and gradient steps. Compared the chromatograms obtained from different conditions and observed that the better separation was attained from $\mathrm{C}_{18}$ column. The final chromatographic separation was optimized and identified on Waters Acquity column HSS T3 $\mathrm{C} 18(150 \mathrm{~mm} \times 2.1 \mathrm{~mm})$ with $1.8 \mu \mathrm{m}$ particles. Ammonium acetate buffer (01. mmol, $\mathrm{pH}$ 5) was used as mobile phase A and acetonitrile used as mobile phase B. The mobile phase flow rate was maintained at $0.3 \mathrm{~mL} \mathrm{~min}^{-1}$. The gradient program for UPLC was set as: time (min)/\% solution B: 0/20, 2/25, 8/ $60,12 / 60,12.5 / 25$ and $18 / 25$. The column temperature was kept as $25^{\circ} \mathrm{C}$ and detected at $230 \mathrm{~nm}$ wavelength. The injection was done by using $2 \mu \mathrm{L}$ volume of solution. The acetonitrile and water $(1: 9 \mathrm{v} / \mathrm{v})$ is used as diluent. The $500 \mu \mathrm{g} \mathrm{mL}^{-1}$ sample concentration is used for RS method and $100 \mu \mathrm{g} \mathrm{mL}^{-1}$ for assay method. The relative retention time (RRT) for impurity 1 is 0.93 (Table-1).

Method validation: The percentage RSD for the DFT peak area responses from replicate injections of assay standard solution for assay method is about 0.4 and for dofetilide and its impurity 1 from replicate injections of CP standard solution are about 0.5 and 0.4 , respectively. The obtained percentage RSD values less than $2 \%$ shows the ability of this method in terms of precision (Table-1).

The study about sensitivity explains about concentration of drug yields signal-to-noise $(\mathrm{S} / \mathrm{N})$ ratio level at 3 for LOD and 10 for LOQ was found to be 0.03 and $0.10 \mu \mathrm{g} \mathrm{mL}^{-1}$, respectively for LOD and LOQ. At LOQ concentration, obtained RSD percentage for impurity 1 peak area responses is below $2 \%$ from precision study.

Critically, it was observed to achieve the resolution between impurity 1 and main compound. To achieve resolution more than 2.0 between main compound and its impurity 1 , various changes were made in buffer concentration, $\mathrm{pH}$ for solution A and column temperatures, etc.. The other parameters like column efficiency in terms of theoretical plates and tailing factor for the main peak were examined and found that all the parameters are within the US Pharmacopeia specification. From the recovery studies, it was observed that achieved recovery percentage results averaging between $98.4-101.8 \%$ for this method. The correlation coefficient $\left(\mathrm{R}^{2}\right)$ was greater than 0.999 from linearity study using different concentration level solutions

\begin{tabular}{|c|c|c|c|c|c|c|c|c|c|c|}
\hline \multicolumn{11}{|c|}{$\begin{array}{c}\text { TABLE } 1 \\
\text { SYTEM SUITABILITY RESULTS }\end{array}$} \\
\hline \multirow[b]{2}{*}{$\begin{array}{l}\text { Compound } \\
\text { name }\end{array}$} & \multicolumn{5}{|c|}{ System suitability from organic impurities solution } & \multicolumn{5}{|c|}{ System suitability from assay standard } \\
\hline & $\mathrm{RT}^{*}$ & RRT\# & $\begin{array}{c}\text { USP } \\
\text { resolution }\end{array}$ & $\operatorname{RSD}(\%)$ & $\mathrm{m} / \mathrm{z}$ value & $\mathrm{RT}^{*}$ & $\begin{array}{c}\text { USP } \\
\text { tailing }\end{array}$ & $\begin{array}{c}\text { USP plate } \\
\text { count }\end{array}$ & $\operatorname{RSD}(\%)$ & $m / z$ value \\
\hline Impurity 1 & 6.60 & 0.93 & - & 0.42 & 428 & - & - & - & - & - \\
\hline Dofetilide & 7.07 & 1.00 & 3.84 & 0.51 & 442 & 6.79 & 0.91 & 498829 & 0.32 & 442 \\
\hline
\end{tabular}

*RT: Retention time; \# RRT: Relative retention time. 
contains main compound and impurity 1 are shown in Table-2. From all the above studies, it was concluded that the developed method was accurate, precise, rugged and robust.

TABLE 2

LINEARITY DATA FOR DOFETILIDE ASSAY AND ORGANIC IMPURITIES

\begin{tabular}{cccc}
\hline Name & $\begin{array}{c}\text { Conc. range }(\mu \mathrm{g} \\
\left.\mathrm{mL}^{-1}\right)\end{array}$ & $\begin{array}{c}\text { Equation of regression } \\
\text { linearity }\end{array}$ & $\mathrm{R}^{2}$ value \\
\hline Dofetilide & $50-150$ & $\mathrm{y}=1 \times 10^{7} \mathrm{x}+2691.8$ & 0.9999 \\
Impurity 1 & $0.005-1.0$ & $\mathrm{y}=191817 \mathrm{x}-544.95$ & 0.9991 \\
\hline
\end{tabular}

Stress studies and degradation behaviour: The stress studies were conducted under acidic and basic hydrolysis, oxidation, photolysis, thermal and humidity conditions to know the degradation behavior of main compound. Dofetilide shows a substantial degradation in $6 \% \mathrm{H}_{2} \mathrm{O}_{2}$ solution for $24 \mathrm{~h}$ at room temperature. Only one degradation product was observed. There is no considerable degradation was observed under other stress conditions like acidic and basic hydrolysis (Fig. 1), oxidation (Fig. 1), photolysis, thermal and humidity, henceforth, drug is stable in these conditions.

By using tools from empower software, peak purity was observed for the peaks obtained from various degradation studies and declared that dofetilide peak was pure and homogeneous from all analyzed stress samples. From stressed samples, mass balance values are calculated and observed that all obtained values are greater than $99.4 \%$. Hence, it is concluded that this developed method is specific to impurity 1 and its degradation products and method was stable.

During stress degradation studies, it was concluded that a single degradation product was formed from dofetilide under oxidation conditions. The clear separation was achieved between dofetilide and its degradation product (Fig. 1). The name for the obtained degradation product is mentioned as degradation product in chromatogram. From these stress studies, it is found that dofetilide is more susceptible towards peroxide degradation. The data from forced degradation studies and drug behaviour are shown in Table-3.

Characterization study of dofetilide and its degradation products: Through MS/MS analysis, a total of three frag- ments were found and identified. A multi stage $\left(\mathrm{MS}^{\mathrm{n}}\right)$ mass fragmentation studies were performed to determine the origin of each fragment ion and this study helps to draw the proposed fragmentation pathway of dofetilide, impurity 1 and its degradation product. To understand the clear degradation patterns of dofetilide, MS spectrum of dofetilide molecular ion $\left([\mathrm{M}+\mathrm{H}]^{+}\right)$ at $m / z 442$ was examined (Fig. 2). The MS/MS spectrum displays product ions at $\mathrm{m} / z 255$ (loss of $\mathrm{C}_{7} \mathrm{H}_{8} \mathrm{NO}_{3} \mathrm{~S}$ ) from $\mathrm{m} / z, 442, \mathrm{~m} / z$ 198 (loss of $\mathrm{C}_{10} \mathrm{H}_{15} \mathrm{~N}_{2} \mathrm{O}_{3} \mathrm{~S}$ ) from $\mathrm{m} / \mathrm{z} 442, \mathrm{~m} / \mathrm{z} 119$ (loss of $\mathrm{C}_{11} \mathrm{H}_{20} \mathrm{~N}_{3} \mathrm{O}_{4} \mathrm{~S}_{2}$ ) from $\mathrm{m} / z$ 442. The proposed fragmentation pathway was derived from MS spectrum obtained from these studies for dofetilide, impurity 1 and its degradation product through chemdraw software. The degradation pathway was proposed for dofetilide is shown in Fig. 3.

A single degradation product was identified from the LCESI-MS spectrum based on observed $[\mathrm{M}+\mathrm{H}]^{+}$ions. Then the characterization for degradation product was performed by selecting molecular ions for $\mathrm{MS}^{\mathrm{n}}$ studies. To confirm the molecular formula of dofetilide, impurity 1 and its degradation product and accurate mass measurements were conducted. The spectra from HRMS study for dofetilide, impurity 1and degradation product are shown in positive mode (Fig. 2). The accurate mass data study for protonated molecules was performed to calculate error between exact and accurate masses (ppm) are tabulated in Table-4. The proposed molecular formulae for fragments are shown in Table-5.

Impurity 1 ( $m / z:$ 427): The MS/MS and HRMS data confirms that the molecular ion at $\mathrm{m} / \mathrm{z} 427$ is from impurity 1 (Fig. 2). From MS spectrum, the product ion at $m / z, 241$ is formed due to loss of $\mathrm{C}_{7} \mathrm{H}_{8} \mathrm{NO}_{3} \mathrm{~S}$ and leads to form $\mathrm{C}_{11} \mathrm{H}_{17} \mathrm{~N}_{2} \mathrm{O}_{2} \mathrm{~S}$ and the chemical name is 2-((4-methylsulfonamide)phenethyl)amino)ethan-1-ylium. The product ion at $\mathrm{m} / \mathrm{z} 198$ is formed due to loss of $\mathrm{C}_{9} \mathrm{H}_{13} \mathrm{~N}_{2} \mathrm{O}_{3} \mathrm{~S}$ and the chemical name is 2-(4-(methylsulonamide)phenyl)ethan-1-ylium. The product ion at $\mathrm{m} / \mathrm{z} 119$ is formed due to loss of $\mathrm{C}_{10} \mathrm{H}_{18} \mathrm{~N}_{3} \mathrm{O}_{4} \mathrm{~S}_{2}$ and the chemical name is 4-(vinyloxyl)benzene-1-ylium. A total of three product ions were observed from fragmentation study of $m / z 427$. The ESIQTOF spectrum showed the molecular formulae of $\mathrm{C}_{19} \mathrm{H}_{27} \mathrm{~N}_{3} \mathrm{O}_{6} \mathrm{~S}_{2}$ with an error of $5.00 \mathrm{ppm}$. The molecular ion with $\mathrm{m} / \mathrm{z} 427$ was characterized as (methylsulfonamido)phenethyl)-

\begin{tabular}{|c|c|c|c|c|}
\hline \multicolumn{5}{|c|}{$\begin{array}{c}\text { TABLE-3 } \\
\text { FORCED DEGRADATION STUDY DATA }\end{array}$} \\
\hline Degradation conditions & $\%$ Degraded, peak name & $\begin{array}{l}\text { Purity } \\
\text { angle }\end{array}$ & $\begin{array}{l}\text { Purity } \\
\text { threshold }\end{array}$ & $\begin{array}{c}\text { Mass } \\
\text { balance }(\%)\end{array}$ \\
\hline $0.1 \mathrm{M} \mathrm{HCl}$ for $24 \mathrm{~h}$ at room temperature & Main peak (no degradation) & 0.237 & 0.341 & 99.5 \\
\hline $0.1 \mathrm{M} \mathrm{NaOH}$ bench top at $24 \mathrm{~h}$ at room temperature & Main peak (no degradation) & 0.247 & 0.345 & 99.4 \\
\hline Stressed with $6 \% \mathrm{H}_{2} \mathrm{O}_{2}, 3 \mathrm{~h} \mathrm{kept} \mathrm{on} \mathrm{bench} \mathrm{top} \mathrm{at} \mathrm{room} \mathrm{temperature}$ & 53.0, Degradation product & 0.221 & 0.315 & 99.6 \\
\hline Thermal at $105^{\circ} \mathrm{C}$ for $48 \mathrm{~h}$ & Main peak (no degradation) & 0.245 & 0.352 & 99.9 \\
\hline $\begin{array}{l}\text { Exposed to visible light for about } 1.2 \text { Million Lux-hours and UV light } \\
\text { for about } 200 \text { Watt-hours/meter square }\end{array}$ & No degradation & 0.218 & 0.329 & 99.8 \\
\hline Ultrasonic for $1 \mathrm{~h}$ & No degradation & 0.251 & 0.375 & 99.9 \\
\hline Humidity $85 \% \mathrm{RH}$ and $85^{\circ} \mathrm{C}$ for 3 days & No degradation & 0.243 & 0.342 & 99.7 \\
\hline
\end{tabular}

\begin{tabular}{cccccc}
\multicolumn{7}{c}{ TABLE4 } \\
\multicolumn{7}{c}{ MASS ACCURACY TABLE FOR DOFETILIDE, IMPURITY 1 AND ITS DEGRADATION PRODUCT } \\
\hline Compound name & Retention time $(\mathrm{min})$ & m.f. & Calculated $m / z$ & Observed $m / z(\mathrm{M}+\mathrm{H})$ & Error $(\mathrm{mDa})$ \\
\hline Dofetilide & 7.29 & $\mathrm{C}_{19} \mathrm{H}_{28} \mathrm{~N}_{3} \mathrm{O}_{5} \mathrm{~S}_{2}$ & 441.1392 & 442.1469 & -0.20 \\
Impurity 1 & 6.86 & $\mathrm{C}_{18} \mathrm{H}_{26} \mathrm{~N}_{3} \mathrm{O}_{5} \mathrm{~S}_{2}$ & 427.1236 & 428.1367 & 1.90 \\
Degradation product & 8.57 & $\mathrm{C}_{19} \mathrm{H}_{28} \mathrm{~N}_{3} \mathrm{O}_{6} \mathrm{~S}_{2}$ & 457.1341 & 458.1383 & 5.12 \\
\hline
\end{tabular}




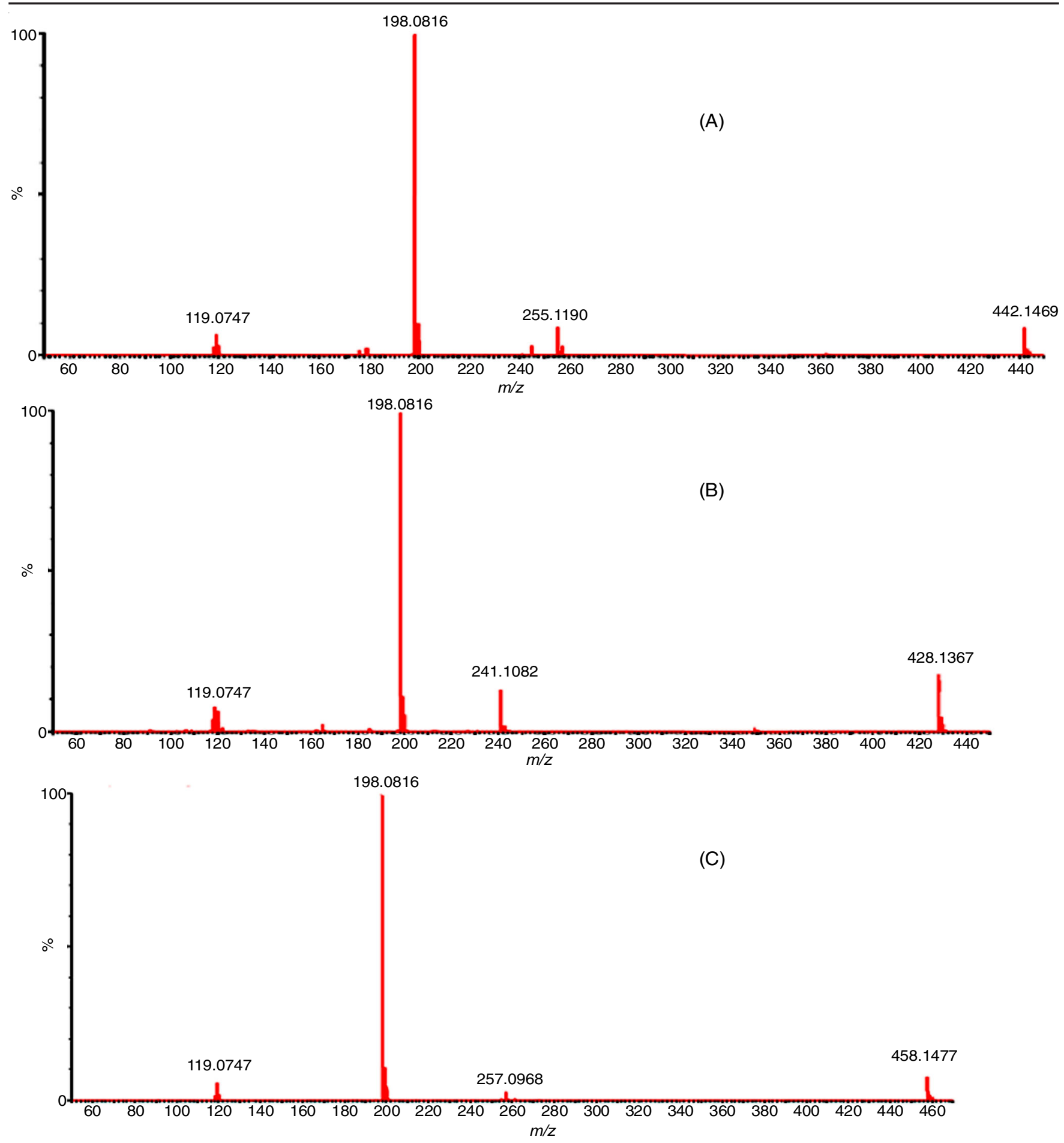

Fig. 2. MS/MS spectra of (A) dofetilide, (B) impurity 1, (C) degradation product

\begin{tabular}{|c|c|c|c|c|c|c|}
\hline \multicolumn{7}{|c|}{$\begin{array}{c}\text { TABLE-5 } \\
\text { MS/MS DATA OF DOFETILIDE, IMPURITY } 1 \text { AND DEGR }\end{array}$} \\
\hline Compound name & $\begin{array}{l}\text { Retention time } \\
\text { (min) }\end{array}$ & m.f. & Observed $\mathrm{m} / \mathrm{z}$ & $\begin{array}{l}\text { m.f. for fragment } \\
\text { ions }(\mathrm{m} / \mathrm{z})\end{array}$ & $\begin{array}{l}\text { Fragment ions } \\
\qquad(\mathrm{m} / \mathrm{z})\end{array}$ & $\begin{array}{l}\text { RDB (ring plus } \\
\text { double bond) }\end{array}$ \\
\hline \multirow{3}{*}{ Dofetilide } & \multirow{3}{*}{7.29} & \multirow{3}{*}{$\mathrm{C}_{19} \mathrm{H}_{28} \mathrm{~N}_{3} \mathrm{O}_{5} \mathrm{~S}_{2}$} & \multirow{3}{*}{442.1469} & $\mathrm{C}_{12} \mathrm{H}_{19} \mathrm{~N}_{2} \mathrm{O}_{2} \mathrm{~S}^{+}$ & 255 & 4.5 \\
\hline & & & & $\mathrm{C}_{9} \mathrm{H}_{12} \mathrm{NO}_{2} \mathrm{~S}^{+}$ & 198 & 4.5 \\
\hline & & & & $\mathrm{C}_{8} \mathrm{H}_{7} \mathrm{O}^{+}$ & 119 & 5.5 \\
\hline \multirow{3}{*}{ Impurity 1} & \multirow{3}{*}{6.86} & \multirow{3}{*}{$\mathrm{C}_{18} \mathrm{H}_{26} \mathrm{~N}_{3} \mathrm{O}_{5} \mathrm{~S}_{2}$} & \multirow{3}{*}{427.1236} & $\mathrm{C}_{11} \mathrm{H}_{17} \mathrm{~N}_{2} \mathrm{O}_{2} \mathrm{~S}^{+}$ & 241 & 4.5 \\
\hline & & & & $\mathrm{C}_{9} \mathrm{H}_{12} \mathrm{NO}_{2} \mathrm{~S}^{+}$ & 198 & 4.5 \\
\hline & & & & $\mathrm{C}_{8} \mathrm{H}_{7} \mathrm{O}^{+}$ & 119 & 5.5 \\
\hline \multirow{3}{*}{$\begin{array}{l}\text { Degradation } \\
\text { product }\end{array}$} & \multirow{3}{*}{8.57} & \multirow{3}{*}{$\mathrm{C}_{19} \mathrm{H}_{28} \mathrm{~N}_{3} \mathrm{O}_{6} \mathrm{~S}_{2}$} & \multirow{3}{*}{457.1341} & $\mathrm{C}_{11} \mathrm{H}_{17} \mathrm{~N}_{2} \mathrm{O}_{3} \mathrm{~S}^{+}$ & 257 & 4.5 \\
\hline & & & & $\mathrm{C}_{9} \mathrm{H}_{12} \mathrm{NO}_{2} \mathrm{~S}^{+}$ & 198 & 4.5 \\
\hline & & & & $\mathrm{C}_{8} \mathrm{H}_{7} \mathrm{O}^{+}$ & 119 & 5.5 \\
\hline
\end{tabular}


<smiles>CCC(C)C</smiles>

Chemical formula: $\mathrm{C}_{19} \mathrm{H}_{28} \mathrm{~N}_{3} \mathrm{O}_{5} \mathrm{~S}_{2}{ }^{+}$

Exact mass: 442.15

Molecular weight: 442.57<smiles>C=COC1=CC=[C+]C=C1</smiles><smiles>CCN(C)CCc1ccc(NS(C)(=O)=O)cc1</smiles>

Chemical formula: $\mathrm{C}_{12} \mathrm{H}_{20} \mathrm{~N}_{2} \mathrm{O}_{2} \mathrm{~S}$

Exact mass: 256.12

\section{$-\mathrm{C}_{11} \mathrm{H}_{20} \mathrm{~N}_{3} \mathrm{O}_{4} \mathrm{~S}_{2}$

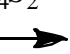

Chemical formula: $\mathrm{C}_{8} \mathrm{H}_{8} \mathrm{O}$

Exact mass: 120.06

Fig. 3. Mass fragmentation pathway of dofetilide

amino)ethoxy)phenyl)methanesulfonamide. The impurity 1 fragmentation pathway is shown in Fig. 4.

Degradation product $(m / z, 458)$ : The spectrum from LC/ MS/MS confirms that molecular ion at $m / z, 458$ is from degra- dation product (Fig. 2). From MS/MS spectrum, the product ion at $m / z, 257$ is formed due to loss of $\mathrm{C}_{8} \mathrm{H}_{10} \mathrm{NO}_{3} \mathrm{~S}$ and leads to form $\mathrm{C}_{11} \mathrm{H}_{17} \mathrm{~N}_{2} \mathrm{O}_{3} \mathrm{~S}$ and the chemical name is (methylsulonamido)phenethyl)methyliumamine oxide. The product ion at<smiles>CS(=O)(=O)Nc1ccc(CCNCCOc2ccc(NS(C)(=O)=O)cc2)cc1</smiles>

Chemical formula: $\mathrm{C}_{18} \mathrm{H}_{26} \mathrm{~N}_{3} \mathrm{O}_{5} \mathrm{~S}_{2}{ }^{+}$<smiles>C=COC1=CC=[C+]C=C1</smiles>

$\stackrel{-\mathrm{C}_{10} \mathrm{H}_{18} \mathrm{~N}_{3} \mathrm{O}_{4} \mathrm{~S}_{2}}{\longrightarrow}$ Chemical formula: $\mathrm{C}_{8} \mathrm{H}_{7} \mathrm{O}^{+}$

Exact mass: 119.05

Exact mass: 428.13

Molecular weight: 428.54<smiles>CCNCCc1ccc(NS(C)(=O)=O)cc1</smiles>

Chemical formula: $\mathrm{C}_{11} \mathrm{H}_{17} \mathrm{~N}_{2} \mathrm{O}_{2} \mathrm{~S}^{+}$<smiles>[CH2+]Cc1ccc(NS(C)(=O)=O)cc1</smiles>

Chemical formula: $\mathrm{C}_{9} \mathrm{H}_{12} \mathrm{NO}_{2} \mathrm{~S}^{+}$

Exact mass: 198.0583

Exact mass: 241.1005

Fig. 4. Mass fragmentation pathway of impurity 1 


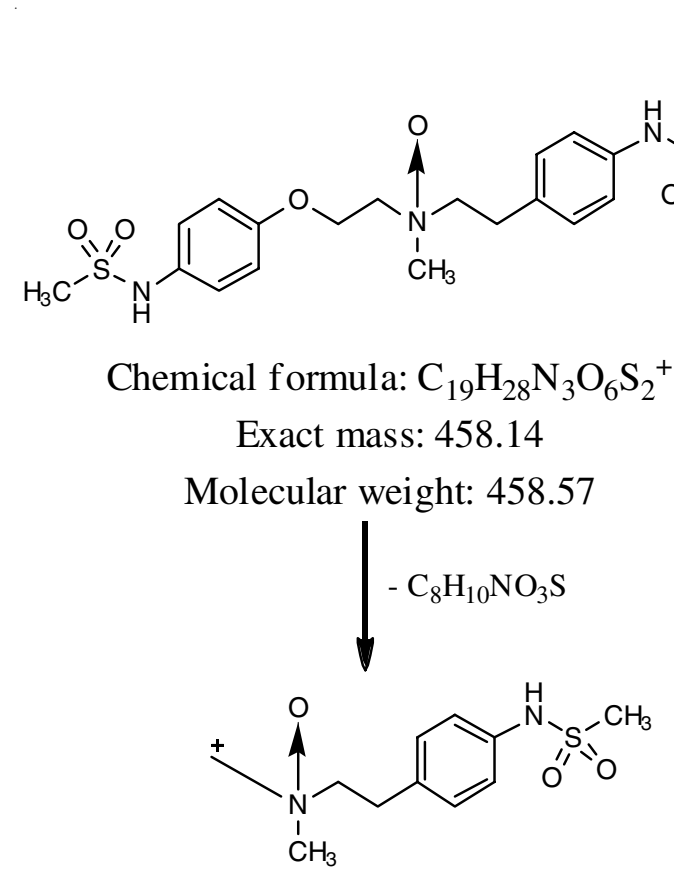

Chemical formula: $\mathrm{C}_{11} \mathrm{H}_{17} \mathrm{~N}_{2} \mathrm{O}_{3} \mathrm{~S}^{+}$

Exact mass: 257.10<smiles>C=COc1ccccc1</smiles>

Chemical formula: $\mathrm{C}_{8} \mathrm{H}_{7} \mathrm{O}^{+}$

Exact mass: 119.05

Fig. 5. Mass fragmentation pathway of degradation product

$m / z, 198$ is formed due to loss of $\mathrm{C}_{10} \mathrm{H}_{15} \mathrm{~N}_{2} \mathrm{O}_{4} \mathrm{~S}$ and the chemical name is 2-(4-(methylsulonamide)phenylethan-1-ylium. The product ion at $m / z, 119$ is formed due to loss of $\mathrm{C}_{11} \mathrm{H}_{20} \mathrm{~N}_{3} \mathrm{O}_{5} \mathrm{~S}_{2}$ and the chemical name is 4-(vinyloxyl)benzene-1-ylium. A total of three product ions were observed from fragmentation study of $m / z 458$. The ESI-QTOF spectrum showed the molecular formulae of $\mathrm{C}_{19} \mathrm{H}_{27} \mathrm{~N}_{3} \mathrm{O}_{6} \mathrm{~S}_{2}$ with an error of $5.00 \mathrm{ppm}$. The molecular ion with $m / z 457$ was characterized as N-methyl$\mathrm{N}$-(4-(methylsulfonamideo)phenethyl)-2-(4-(methylsulfonamide)phenoxy)ethan-1-amine oxide. The fragmentation pathway of degradation product is shown in Fig. 5.

\section{Conclusion}

A new method was developed and validated through UPLC system with mobile phase having LC-MS compatibility. LCMS stability indicating method helps to describe the stress degradation behaviour of dofetilide under various conditions like hydrolysis (acid, base and neutral), oxidation, photolysis, and thermal. The present developed method can be used for the both quantification and qualification studies for determination of dofetilide in API, formulations and stability samples. The structural characterization and mass accuracy studies were performed for dofetilide, impurity 1 and its degradation product respectively formed under peroxide degradation using LC/MS/ MS technique to confirm the proposed fragmentation pathway for degradation product is accurate. This method helps to develop reference standards for the identified degradation product from main compound and helps in continuous monitoring of degradation product presence in the stability studies samples.

\section{CONFLICT OF INTEREST}

The authors declare that there is no conflict of interests regarding the publication of this article.

\section{REFERENCES}

1. J.P. Mounsey and J.P. DiMarco, Circulation, 102, 2665 (2000); https://doi.org/10.1161/01.CIR.102.21.2665.

2. N. Kaddar, S. Pilote, S. Wong and B. Caillier, J. Chromatogr. Sep. Technol., 4, 192 (2013);

https://doi.org/10.4172/2157-7064.1000192.

3. R. Arunkumar, A. Ruckmani, L.R. Prabhu, P.G. Nayar, M. Chokkalingam, D. Rajasekaran and A.O. Arumugam, World J. Pharm. Res., 3, 511 (2014).

4. B. Kousar, A. Aditya, N. Charan, T.K. Vinay and B.S. Chandra Rao, J. Pharma Res., 6, 108 (2017).

5. K.R. Sangeetha, K.T. Ravi and M. Gandhimathi, Eur. J. Pharm. Med. Res., 4, 520 (2017).

6. Dofetilide USP Monograph, Version USP38/NF33, The United States Pharmacopeia, Maryland, Rockville, USA, 35, 1135 (2016).

7. International Conference on Harmonization, ICH Guidelines, Impurities in New Drug Substances, Topic Q3A (R2), Geneva, Switzerland (2006).

8. M.A. Babu, C.V.K. Mohan, J. Satish, P.D. Kalariya, C.H.K. Raju and S.D. Mankumare, J. Appl. Pharm. Sci., 8, 65 (2018); https://doi.org/10.7324/JAPS.2018.8609.

9. International Conference on Harmonization, ICH Guidelines, Stability testing of New Drug Substances and Products, Topic Q1A (R2), Geneva, Switzerland (2003).

10. K.R. Chintalapati, S.K. Jagarlapudi and K.G. Sanath, New J. Chem., 42, 634 (2018); https://doi.org/10.1039/C7NJ02781H.

11. International Conference on Harmonization, ICH Guidelines, Validation of Analytical Procedures: Text and Methodology, Topic Q2 (R1), Geneva, Switzerland (2005). 